\title{
Komodifikasi Kritik Sosial dalam Film Sexy Killers
}

\author{
Helsa Dhyanti Mustika*, Septiawan Santana Kurnia \\ Fakultas Ilmu Komunikasi, Universitas Islam Bandung, Indonesia \\ *helsadhyantimustika21@gmail.com, septiawansantana@gmail.com
}

\begin{abstract}
The mass media is one source of information that is currently used easily by the public. With the development of communication technology today, people can easily access all information. Researchers used qualitative research methods. This research uses Theo Van Leeuwen's Critical Discourse Analysis. The results of the study carried out by these shows that the marginalization in the Sexy Killers movie dialogue text indicated that the marginalized groups in this study were farmers and surrounding communities living in areas near coal excavations and the construction of a power plant. The discourse of exclusion which includes passivation, nomination and substitution of clauses is contained in the text of the dialogue. While the discourse of exclusion with 7 categories also exists in this study except assimilation-individualization. While the discourse of social criticism in this study arises because of the dialogue from the surrounding community deliberately raised by researchers. The results of this study that the discourse of exclusion and inclusion as well as the discourse of social criticism in the film Sexy Killers successfully raised by the filmmaker. The result is readers and the audience who watch the film know how the actual conditions occur, as well as the impact on the surrounding community.
\end{abstract}

Keywords: Theo Van Leeuwen, Commodification, Social Criticism, Film Sexy Killers, WatchDoc

\begin{abstract}
Abstrak. Media massa merupakan salah satu sumber informasi yang saat ini digunakan secara mudah oleh masyarakat. Dengan berkembangnya teknologi komunikasi saat ini, masyarakat dapat dengan mudah mengakses segala informasi. Peneliti menggunakan metode penelitian kualitatis. Penelitian ini menggunakan Analisis wacana Kritis milik Theo Van Leeuwen. Hasil penelitian yang dilakukan oleh tersebut menunjukan bahwa pemarjinalan dalam teks dialog film Sexy Killers tersebut tertera kelompok yang termarjinalkan dalam penelitian ini adalah para petani dan masyarakat sekitar yang tinggal di daerah dekat penggalian batu bara dan pembangunan PLTU. Wacana eksklusi yang meliputi pasivasi, nominalisasi, dan penggantian anak kalimat terdapat dalam teks dialog tersebut. Sementara wacana eksklusi dengan 7 kategori terdapat pula dalam penelitian ini kecuali asimilasi-individualisasi. Sementara wacana kritik social dalam penelitian ini muncul karena adanya dialog dari masyarakat sekitar yang sengaja dimunculkan oleh peneliti. Hasil dari penelitian ini bahwa wacana eksklusi dan inklusi juga wacana kritik social dalam film Sexy Killers berhasil dimunculkan oleh pembuat film tersebut. Hasilnya pembaca dan khalayak yang menonton film tersebut mengetahui bagaimana kondisi yang sebenarnya terjadi, juga dampak bagi masyarakat sekitarnya.
\end{abstract}

Kata Kunci: Theo Van Leeuwen, Komodifikasi, Kritik Sosial, Film Sexy Killers, WatchDoc 


\section{A. Pendahuluan}

Dewasa ini, teknologi telah memengaruhi manusia untuk melakukan aktivitasnya sehari-hari. Dari mulai melakukan sebuah komunikasi hingga mencari berbagai informasi. Perkembangan teknologi yang pesat mendorong masyarakat atau yang bisa kita sebut juga dengan khalayak pengguna sebuah media untuk semakin berkembang dan menambah wawasannya. Khalayak daoat dengan mudah mengakses berbagai produk teknologi zaman sekarang. Media social sebagai salah satunya.

Saat ini, bukan hanya khalayak yang menggunakan sebuah media social, tetapi para pemilik media juga ikut memanfaatkannya. Di era teknologi seperti ini, khalayak menggunakan media social sebagai salah satu sarana untuk mendapatkan informasi, meskipun saat ini para pemilik media masih memproduksi dan menyebarluaskan surat kabar. Melihat hal tersebut, para pemilik media pun turut menggunakan media social dengan cara membuat akun resmi pada setiap media sosialnya. Mereka mengunggah berita-berita melalui akun resminya dalam media social. Selain memudahkan khalayak untuk mengaksesnya, media social juga memudahkan para pemilik media untuk menyebarluaskan beritanya.

Dalam film dokumenter karya Watchdoc di kanal Youtube ini menceritakan bagaimana industri batu bara berkembang di Indonesia, terdapat banyak adegan yang memperlihatkan bagaimana dampak bagi masyarakat yang tinggal di daerah pembuatan industri batubara tersebut. Tidak hanya itu, film ini pun menguak tentang dalang-dalang atau pemilik perusahaan batu bara, Pembangkit Listrik Tenaga Uap (PLTU), dan semena-menaan industri tersebut kepada masyarakat sekitar.

Maka dari itu pada penelitian kali ini, peneliti ingin sekali melihat bagaimana komodifikasi kritik sosial yang terdapat dalam film Sexy Killers tersebut. Peneliti sangat mengharapkan bahwa hasil dari penelitian ini membuktikan bahwa suatu film yang branding dalam kanal Youtube karya Watchdoc tersebut mengandung kritik sosial yang baik sehingga tidak ada pihak manapun yang merasa adanya marjinalisasi dalam film yang saat itu sempat menjadi trending topic di tengah-tengah hangatnya pemberitaan mengenai pencalonan presiden. Film ini viral karena terdapat nama-nama pemilik tambang yang ternyata pada saat itu mencalonkan menjadi Presiden dan Wakil Presiden.

Berdasarkan pendahuluan diatas maka memunculkan pertanyaan penelitian sebagai berikut : (1) bagaimana wacana teks Eksklusi komodifikasi kritik social dalam film Sexy Killers di kanal YouTube WatchDoc; (2) bagaimana wacana teks Inklusi komodifikasi kritik social dalam film Sexy Killers di kanal YouTube WatchDoc; (3) bagaimana wacana kritik social dalam film Sexy Killers di kanal YouTube WatchDoc.

Selanjutnya, tujuan dari penelitian ini adalah :

1. Untuk mengetahui wacana teks Eksklusi komodifikasi kritik social dalam film Sexy Killers di kanal YouTube WatchDoc

2. Untuk mengetahui wacana teks Inklusi komodifikasi kritik social dalam film Sexy Killers di kanal YouTube WatchDoc

3. Untuk mengetahui wacana kritik social dalam film Sexy Killers di kanal YouTube WatchDoc

\section{B. Landasan Teori}

Dalam penelitian ini peneliti menggunakan metode penelitian kualitatif. Seperti yang kita ketahui bahwa metode merupakan suatu cara penelitian yang terstruktur dalam mempertimbangkan pemikiran-pemikiran dengan baik dengan tujuan untuk mencapai maksud dari penelitian tersebut. Menurut Djajasudarna (2010: 1), "Metode adalah cara yang teratur dan terpikir untuk mencapai maksud cara kerja yang bersistem untuk memudahkan pelaksanaan suatu kegiatan guna mencapai tujuan yang telah ditentukan."

Pendekatan yang dipakai yaitu Analisis Wacana Kritis menyediakan teori dan metode yang bisa digunakan untuk melakukan kajian empiris tentang hubungan-hubungan antara wacana dan perkembangan sosial dan kultural dalam domain-domain sosial yang berbeda. Dalam analisis wacana kritis wacana di sini tidak dipahami semta sebagai studi bahasa. 
Menurut Fairclough dan Wodak, analisis wacana kritis melihat wacana-pemakaian bahasa dalam tuturan dan tulisan- sebagai bentuk dari praktik sosial (Eriyanto, 2011:7). Menggambarkan wacana sebagai praktik sosial menyebabkan sebuah hubungan dialektis di antara peristiwa diskursif tertentu dengan situasi, institusi, dan struktur sosial yang membentuknya.

Penelitian ini menggunakan analisis wacana Theo Van Leeuwen yang berfokus tentang representasi aktor sosial. Analisis tersebut menampilkan tentang pihak-pihak dan aktor yang ditampilkan dalam pemberitaan. Bagaimana suatu kelompok dominan lebih memegang kendali, sementara kelompok lain yang posisinya rendah cenderung untuk terus menerus dijadikan objek pemaknaan dan digambarkan secara buruk. Kelompok buruh, petani, nelayan, imigran gelap, dan wanita adalah kelompok yang bukan hanya tidak mempunyai kekuatan dan kekuasaan, namun juga dalam wacana bahwa berdemonstrasi sering ditindak dengan kekerasan, setelah terbentuk wacana bahwa demonstrasi dan pemogokan buruh itu banyak menimbulkan keonaran, kemacetan, dan kekuasaan (Eriyanto, 2009 : 171).

Dalam analaisis Van Leeuwen, berfokus kepada dua hal. Pertama adalah proses pengeluaran (exclusion). Van Leeuwen (2008:28) berkata bahwa Exclusion menjadi bagian yang sangat penting dalam analisis wacana kritis. Ekslusi yaitu apakah dalam suatu teks berita ada kelompok atau aktor yang dikeluarkan dalam pemberitaan, yang dimaksudkan dengan pengeluaran seseorang atau aktor dalam pemberitaan adalah, menghilangkan atau menyamarkan pelaku/aktor dalam berita, sehingga dalam berita korbanlah yang menjadi perhatian berita. Proses pengeluaran ini secara tidak langsung bisa mengubah pemahaman khalayak akan suatu isu dan melegistimasi posisi pemahaman tertentu. Kedua, proses pemasukan (inclusion). Proses ini adalah lawan dari proses exclusion, proses ini berhubungan dengan bagaimana seseorang atau kelompok aktor dalam suatu kejadian dimasukkan atau dipresentasikan ke dalam sebuah berita.

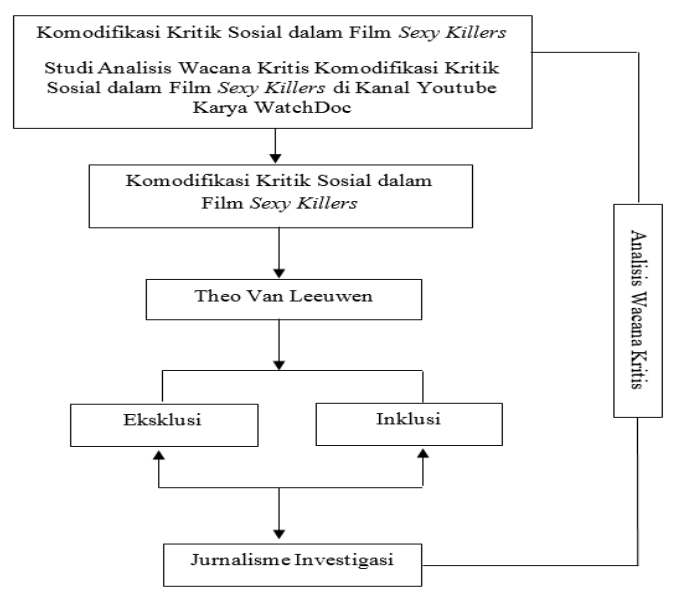

Gambar 1. Kerangka Pemikiran

\section{Hasil Penelitian dan Pembahasan}

Pada pembahasan kali ini peneliti akan memaparkan temuan yang telah dikumpulkan. Dalam penelitian ini peneliti menggunakan metode kualitatif dengan pendekatan Analisis Wacana Kritis (AWK) menurut Theo Van Leeuwen dengan tujuan untuk mencari tahu bagaimana eksklusi, inklusi juga wacana kritik social yang terkandung dalam film Sexy Killers.

Untuk mengetahui hasil akhirnya, peneliti mengumpulkan data yang didapatkan melalui hasil analisis teks, studi kepustakaan dan wawancara. Ada beberapa strategi tentang bagaiaman suatu actor baik seseorang ataupun kelompok dikeluarkan, dihilangkan, atau dikucilkan posisinya dalam sebuah pembicaraan. Analisis Van Leeuwen secara umum menampilkan bagaimana pihak-pihak dan actor ditampilkan dalam pemberitaan. Leeuwen menggunakan pendekatan eksklusi dan inklusi untuk menganalisis bagaimana actor-aktor dalam wacana 
tersebut ditampilkan

Proses eksklusi sendiri direalisasikan melalui tiga strategi, yaitu pasivasi (penghilangan actor dalam wacana yang paling umum dilakukan dengan menggunakan kalimat pasif untuk menjabarkan peristiwa), nominalisasi (proses mengubah verba menjadi nomina) dan penggantian anak kalimat. Berlawanan dengan eksklusi, inklusi berkaitan dengan bagaimana actor dimasukan atau dihadirkan dalam wacana. Selain proses eksklusi, Van Leeuwen juga mengemukakan tentang proses inklusi. Proses inklusi ini direalisasikan melalui 7 strategi yaitu diferensiasi-indeferensiasi (menghadirkan actor atau peristiwa lain sebagai pembanding), objektivasi-abstraksi, nominasi-kategorisasi-nominasi-identifikasi, determinasi-indeterminasi, dan asimilasi-individualisasi, asosiasi-disosiasi.

\section{Wacana Eksklusi dalam film Sexy Killers di kanal YouTube WatchDoc}

Dalam penelitian ini proses eksklusi sendiri direalisasikan melalui tiga strategi yaitu pasivasi, nominalisasi, juga anak kalimat. Pasivasi berarti menjelaskan tentang bagaimana penghilangan actor dalam wacana yang paling umum dilakukan dengan menggunakan kalimat pasif untuk menjabarkan suatu peristiwa. Selanjutnya ada nominalisasi yang berarti proses mengubah teks verba menjadi nomina, dan yang terakhir adalah penggantian anak kalimat.

\section{Pasivasi}

Pasivasi merupakan suatu isu yang sentral dalam analisis wacana. Pada dasarnya hal tersebut membahas mengenai suatu kelompok atau actor tertentu tidak dilibatkan dalam suatu pembicaraan atau wacana. Penghilangan actor sosial ini melindungi dirinya. Berikut adalah kutipan dari dialog dalam film Sexy Killers yang telah di buat oleh peneliti

Tabel 1. Contoh kalimat Pasivasi

\begin{tabular}{|l|l|}
\hline No & Contoh kalimat Pasivasi \\
\hline 1 & $\begin{array}{l}\text { Gubernur : (15:44) waspada, harusnya masyarakat tau waspada ada lobang ya } \\
\text { kita sudah sampaikan, sebarkan ke seluruh, coba itu kan sudah ditandai jangan } \\
\text { sampai ada yang kena, tapi masih ada lagi, jangan-jangan ada hantunya itu }\end{array}$ \\
\hline
\end{tabular}

Ada akibat buruk yang ditimbulkan dari pola ini yaitu actor atau pelaku hilang dari pemberitaan. Dengan tujuan actor yang dihilangkan adalah yang seolah menghilangkan para petani atau masyarakat yang tinggal di sekitar. Kalimat pasif yang menghilangkan actor dari kalimat tersebut juga membuat khalayak yang menonton tidak kritis. Ditimbulkan karena adanya bantahan-bantahan dari pemilik tambang yang menyebutkan atau memfokuskan bahwa galian tambang sebetulnya bisa saja tidak di urug kembali melainkan dibuat tempat rekreasi bagi masyarakat sekitar.

\section{Nominalisasi}

Selanjutnya adalah strategi yang sering dipakai oleh penelitian lainnya untuk menghilangkan kelompok atau factor sosial tertentu adalah lewat nominalisasi. Ini berhubungan langsung dengan mengubah kata kerja verba menjadi kata benda nomina. Nominalisasi tidak membutuhkan subjek atau actor karena adanya proses mengubah kata kerja yang bermakna tindakan atau kegiatan menjadi kata benda yang bermakna peristiwa. Kehadiran actor tersebut dapat dihilangkan. Maka dari itu nominalisasi bisa menghilangkan subjek atau pelaku tindakan. Kata nominalisasi tidak hanya bisa menghilangkan subjek, namun juga dapat mengubah makna kalimat ketika diterima khalayak. 
Tabel 2. Contoh kalimat Nominalisasi

\begin{tabular}{|l|l|}
\hline No & Contoh kalimat Nominalisasi \\
\hline 1 & $\begin{array}{l}\text { Luhut saat di wawancarai : (23:08) ratusan ribu hektar, saya punya lahan } \\
\text { tambang betul tapi ya gak ratusan ribu hektarlah anu tambang batu bara. }\end{array}$ \\
\hline
\end{tabular}

\section{Penggantian Anak Kalimat}

Dalam penelitian ini penghilangan actor dengan cara penggantian anak kalimat dilakukan agar tidak terfokus pada actor yang memiliki keluhan. Dapat dilihat pada kolom dibawah ini, diambil dari teks dialog dalam film Sexy Killers.

Tabel 3. Contoh kalimat Penggantian Anak Kalimat

\begin{tabular}{|c|c|}
\hline No & Contoh kalimat Penggantian Anak Kalimat \\
\hline 1 & $\begin{array}{l}\text { Pada saat rapat komisi } 7 \text { DPR dengan pejabat kementrian energy dan sumber } \\
\text { daya mineral serta } 290 \text { pemilik tambang batu bara ini. } \\
\text { C : (18:17) pak mohon maaf ya pak, tambang yang diluar negeri pun kalua digali } \\
\text { itu tidak di urug kembali pak tetapi dijadikan seperti yang tadi dijelaskan ada } \\
\text { respo air }\end{array}$ \\
\hline
\end{tabular}

Dalam penelitian ini, peneliti melihat bagaimana kondisi yang sesungguhnya terjadi seperti udara yang tercemar, kerugian dari masyarakat sekitar, retakan rumah warga, tercemarnya lingkungan, dan lain sebagainya tidak dimunculkan lalu dikedepankan subjek revitalisasi perusaahaan-perusahaan terkait seperti pembuatan tempat wisata, kolam besar, respo air dan lain sebagainya. Juga bantuan pemantauan dari pemerintahan setempat yang membuat para pendengar juga pengamat kehilangan focus kepada pelaku tindakan kelalaian tersebut.

\section{Wacana Inklusi dalam Film Sexy Killers di kanal YouTube WatchDoc}

Strategi selanjutnya yang digunakan adalah dengan menggunakan inklusi. Inklusi merupakan salah satu bagian dari strategi analisis wacana kritis menurut Theo Van Leeuwen. Ada berbagai macam strategi yang digunakan ketika sesuatu, seseorang atau sekelompok ditampilkan dalam sebuah teks. Suatu peristiwa atau seorang actor sosial bisa saja ditampilkan dalam teks secara mandiri, sebagai peristiwa yang unik dank has tetapi bisa juga dibuat kontras dengan menampilkan peristiwa actor lain dalam teks tersebut.

Teks direpresentasikan dalam sebuah teks hal tersebut menjadi penanda yang baik. Penghadiran kelompok atau peristiwa tersebut secara langsung ingin menunjukan bahwa sebuah kelompok itu tidak bagus dibandingkan dengan kelompok yang lainnya. Ada beberapa macam strategi wacana yang dilakukan ketika sesuatu, seseorang atau sekelompok ditampilkan dalam teks dengan diferensiasi-indeferensiasi, objektivasi-abstraksi, nominasi-kategorisasi, nominasiidentifikasi, determinasi-indeterminasi, asimilasi-individualisasi, asosiasi-disosiasi.

\section{Wacana Kritik Sosial dalam Film Sexy Killers di kanal YouTube WatchDoc}

Kritik sosial dalam sebuah film dapat mempengaruhi penontonnya, menampilkan sisi kritik bukan hanya sekedar dari pemiliknya saja tetapi melihat dari sisi lain yang terkena dampaknya. Baik negative ataupun positif sebuah kritik sosial sangat mempengaruhi satu kelompok sosial dalam menanggapi atau berdialog dengan lingkungannya.

Dengan kata lain dapat dikatakan kritik sosial sebagai tindakan adalah membandingkan serta mengamati secara teliti dan melihat perkembangan secara cermat tentang baik atau buruknya kualitas suatu masyarakat. Adapun tindakan mengkritik dapat dilakukan oleh siapapun termasuk sastrawan dan kritik sosial merupakan suatu variable penting dalam memelihara system sosial yang ada. Secara sederhana kritik sosial merupakan salah satu 
kepekaan sosial. Sebuah kritik sosial yang murni tidak didasarkan pada tanggung jawab bahwa manusia bersama-sama bertanggung jawab terhadap lingkungan sosialnya. Kritik sosial adalah sanggahan terhadap hal-hal yang dianggap menyalahi aturan, hokum dan tata nilai yang sudah menjadi konvensi umum.

Tabel 4. Contoh Kalimat Kritik Sosial

\begin{tabular}{|l|l|}
\hline No & Contoh kalimat Kritik Sosial \\
\hline 1 & $\begin{array}{l}\text { Komari : }(6 ; 10) \text { dulu sebelum ada bangunan batu bara sawah ndak rusak, ndak } \\
\text { amburadul sekarang ada bangunan batubara rakyat kecil malah sengsara ya enak } \\
\text { rakyat yang besar ongkang-ongkang kaki terima uang kalua kita terima apa ? } \\
\text { terima imbasnya lumpur. }\end{array}$ \\
\hline
\end{tabular}

\section{Kesimpulan}

Setelah melakukan penelitian mengenai teks dialog dalam film Sexy Killers ini maka peneliti pun dapat mengambil kesimpulan dari hasil analisis tersebut. Kemunculan wacana eksklusi dan inklusi pada penelitian ini ternyata terdapat dan diterapkan. Wacana eksklusi mengenai pasivasi, nominalisasi, dan penggantian anak kalimat. Dalam penelitian ini wacana eksklusi banyak terdapat setelah peneliti membuat transkrip dialognya. Hasilnya penghilangan actor dalam wacana dialog film Sexy Killers ini dilakukan oleh pihak perusahaan, juga pemerintah yang membebankan banyak kepada masyarakat, tidak mendengar suara rakyat. Sementara Inklusi direalisasikan melalui 7 startegi, diferensiasi-indeferensiasi, objektivasi-abstraksi, nominasikategorisasi, nominasi identifikasi, determinasi-indeterminasi, dan asimilasi-individualisasi. Dalam penelitian ini strategi determinasi-indeterminasi tidak ditemukan oleh peneliti tetapi 6 strategi lainnya terdapat dalam teks dialog Sexy Killes tersebut. Hasil dari penelitian ini bahwa strategi Inklusi terdapat dalam penelitian ini, berabagai dialog yang terlampir banyak membuktikan bahwa penghardiran actor yang termarjinalkan posisinya benar-benar terjadi.

Selanjutnya untuk wacana kritik social yang terdapat dalam film Sexy Killers tersebut lebih banyak muncul. Karena focus penelitian menampilkan kritik social ini berhasil dengan banyaknya dialog dari masyarakat. Masyarakat sekitar yang merasakan dampak dari penggalian tersebut sangat dirugikan bahkan menimbulkan korban jiwa. Pertanggung jawaban dalam kasus ini sangat di butuhkan oleh masyarakat sekitar. Dengan adanya film documenter ini masyarakat terbantu untuk mendapatkan pertanggung jawaban.

\section{E. Saran}

\section{Saran Teoritis}

Penelitian ini diharapkan dapat bermanfaat bagi mahasiswa atau studi komunikasi sebagai referensi, pendalaman, perkembangan, dan acuan untuk penelitian berikutnya.

\section{Saran Praktis}

Peneliti mengharapkan bahwa penelitian ini dapat bermanfaat bagi para industry media terutama para pembuat film documenter dengan mengutamakan kebenaran dan fakta yang ada di lapangan menampilkan karyanya sesuai dengan kaidah yang telah ditentukan.

\section{Daftar Pustaka}

[1] Aaker, A. David. 2002. Ekuitas Merek (Edisi Indonesia). Jakarta: Mitra Utama.

[2] Alma, Buchari. 2006. Manajemen Pemasaran dan Pemasaran Jasa. Bandung: Alvabeta.

[3] Arikunto, Suharsimi. 2006. Prosedur Penelitian Suatu Pendekatan Praktek. Jakarta: Rineka Cipta.

[4] Azwar, Syaifuddin. 2005. Metode Penelitian. Jogyakarta: Pustaka Belajar. 
[5] Cangara, H. Hafied. 2002. Pengantar Ilmu Komunikasi. Jakarta: Raja Grafindo Persada.

[6] Darmadi, Sugianto dkk. 2010. Inovasi Pasar dengan Iklan yang Efektif (Strategi, Program dan Teknik Pengukuran). Jakarta: Gramedia Pustaka Utama.

[7] Durianto, Darmadi dan C. Liana. 2001. Analisis Efektifitas Iklan Televisi Softener Soft \& Fresh di Jakarta dan Sekitarnya dengan Menggunakan Consumer Decision Model. Jurnal Ekonomi Perusahaan. Volume IV Nomor 